JRPB, Vol. 7, No. 2, September 2019, Hal. 166-173

DOI: $10.29303 /$ jrpb.v7i2.124

ISSN 2301-8119, e-ISSN 2443-1354

Tersedia online di http://jrpb.unram.ac.id/

\title{
ANALISIS VARIASI JENIS DAN PANJANG SUMBU TERHADAP PERTUMBUHAN TANAMAN PADA SISTEM HIDROPONIK
}

Analysis of Type and Length Axis Variations on Plant Growth in Hydroponic Systems

\section{Ansar $^{1, *}$, Guyup Mahardhian Dwi Putra ${ }^{1}$, Opan Sopiandi Ependi ${ }^{1}$}

${ }^{1}$ Program Studi Teknik Pertanian, Fakultas Teknologi Pangan dan Agroindustri, Universitas Mataram

E-mail ${ }^{*}$ : ansar72@unram.ac.id

Diterima: Juli 2019

Disetujui: September 2019

\begin{abstract}
This study aims to observe the effect of the type and length of the axis on the growth rate and development of mustard plants (Brassica Juncea L.) and analyze the effect of water circulation on the growth and development of mustard plants. The study uses factorial patterns with two types of treatments, namely the type of axis and the length of the axis. Each treatment is done 3 times. The parameters observed were ambient temperature, air humidity, light intensity, evapotranspiration, and plant growth. The results showed that the type of axis affected the growth rate and development of mustard plants. Coconut coir axes have more leaves than the flannel axis. The results of plant growth with a water circulation system is better when compared to a system without water circulation. This can be proven based on the average number of leaves and plant height.
\end{abstract}

Keywords: flannel cloth, coconut fiber, circulation, hydroponic systems

\begin{abstract}
ABSTRAK
Penelitian ini bertujuan mengamati pengaruh variasi jenis dan panjang sumbu terhadap laju pertumbuhan dan perkembangan tanaman sawi (Brassica Juncea L.) dan menganalisis pengaruh sirkulasi air terhadap pertumbuhan dan perkembangan tanaman sawi. Penelitian menggunakan pola faktorial dengan dua jenis perlakuan, yaitu jenis sumbu dan panjang sumbu. Setiap perlakuan dilakukan 3 kali pengulangan. Parameter yang diamati adalah suhu lingkungan, kelembaban udara, intensitas cahaya, evapotranspirasi, dan pertumbuhan tanaman. Hasil penelitian menunjukkan bahwa jenis sumbu berpengaruh terhadap laju pertumbuhan dan perkembangan tanaman sawi. Sumbu sabut kelapa memiliki jumlah daun lebih banyak dibandingkan dengan sumbu flanel. Hasil pertumbuhan tanaman dengan sistem sirkulasi air lebih baik jika dibandingkan dengan sistem tanpa sirkulasi air. Hal ini dapat dibuktikan dari hasil rata-rata jumlah daun dan tinggi tanaman.
\end{abstract}

Kata kunci: kain flanel, sabut kelapa, sirkulasi, sistem hidroponik 


\section{PENDAHULUAN}

\section{Latar Belakang}

Seiring dengan meningkatnya populasi penduduk dunia berarti meningkat pula kebutuhan pangan dan kebutuhan pokok lainnya, membuat penggunaan lahan pertanian semakin berkurang. Seperti dikatakan oleh Sopandie (2006), laju peningkatan jumlah penduduk yang terus meningkat serta pemanfaatan lahan pertanian yang subur oleh kepentingan sektor non pertanian memaksa sektor pertanian harus bergeser pada pemanfaatan lahan kering atau marjinal dengan tingkat kesuburan yang rendah dan berbagai cekaman abiotik secara optimum. Selain itu, penggunaan pupuk dan pestisida yang berlebihan. Hal ini berdampak bagi rendahnya kualitas dan kuantitas produksi pertanian dan kebutuhan bahan pangan untuk memenuhi kebutuhan masyarakat.

Pertanian merupakan salah satu sumber penghasil devisa negara melalui peningkatan ekspor dan atau pengurangan ketergantungan negara terhadap impor atas komoditi pertanian. Oleh karena itu, Indonesia perlu meningkatkan kualitas hasil produksi pertanian khususnya di bidang pangan supaya menghasilkan suatu produk yang bersih dan memiliki gizi yang aman, agar hasil dari pertanian Indonesia dapat bersaing di pasar dalam negeri maupun di luar negeri.

Untuk meningkatkan kesuburan lahan pertanian dan produktivitas tanaman dapat dilakukan dengan cara hidroponik. Hidroponik merupakan cara bercocok tanam tanpa menggunakan media tanah, melainkan hanya menggunakan air atau bahan porous lainnya seperti kerikil, pecahan genteng, arang sekam, pasir, dan batu bata (Lingga, 2005).

Sistem sumbu (wick) merupakan salah satu sistem hidroponik. Sistem sumbu memanfaatkan prinsip kapilaritas larutan nutrisi yang diserap langsung oleh tanaman melalui sumbu (Lee, et all., 2010). Salah satu bahan yang memiliki daya serap air terbaik dan dapat digunakan sebagai sumbu pada sistem sumbu adalah bahan kain flanel (Wesonga, et all., 2014). Kelebihan penggunaan kain flanel sebagai material untuk sumbu adalah mampu menyerap air dengan baik, namun harganya mahal. Alternatif lain yang bisa digunakan sebagai sumbu adalah sabut kelapa. Sabut kelapa ini mudah didapatkan, harganya murah, dan tersedia sangat melimpah. Selain itu, sabut kelapa banyak mengandung unsur hara yang dapat memicu petumbuhan tanaman. Salah satu unsur hara yang terkandung dalam sabut kelapa adalah unsur hara Nitrogen, Fosforus, dan Kalsium (NPK) yang diperlukan oleh tanaman (Mas'ud, 1993).

Hal yang perlu diperhatikan pada metode budidaya hidroponik adalah larutan nutrisi. Larutan nutrisi merupakan sumber pasokan nutrisi bagi tanaman untuk mendapatkan makanan dalam budidaya hidroponik. Selain larutan nutrisi, faktor lain yang mempengaruhi pertumbuhan tanaman adalah media tanam. Fungsi dari media tanam ini adalah sebagai tempat tumbuh dan penyimpanan unsur hara yang diperlukan untuk pertumbuhan tanaman (Aulia, dkk., 2019).

Sayuran merupakan komoditas penting dalam mendukung ketahanan pangan nasional. Komoditas ini memiliki keragaman yang luas dan berperan sebagai sumber karbohidrat, protein nabati, vitamin, dan mineral yang bernilai ekonomi tinggi (Adiyoga, 1999).

Sawi hijau merupakan jenis sayur yang digemari oleh masyarakat Indonesia. Konsumennya mulai dari golongan masyarakat kelas bawah hingga golongan masyarakat kelas atas. Sawi mengandung berbagai zat gizi yang sangat dibutuhkan tubuh, antara lain vitamin $\mathrm{K}$, A, C, E, folat, mangan, dan serat pangan (Cahyono, 2003).

Rendahnya tingkat konsumsi tersebut berkaitan dengan minimnya tingkat produksi pangan yang dialami oleh petani Indonesia. Salah satu solusi untuk meningkatkan produksi pangan seperti sayuran adalah bertanam secara hidroponik baik tanpa atau dengan greenhouse. Beberapa tahun terakhir ini perkebunan hidroponik bermunculan dan digemari masyarakat. Keuntungan teknologi tersebut antara lain dapat menghemat biaya investasi sekitar 38\%, mampu menghasilkan sayuran yang dipersyaratkan pasar, pemberian nutrisi yang sesuai membuat tanaman sehat, sehingga dapat 
bertahan dari serangan hama dan penyakit (Rosliani dan Sumarni, 2005).

Berdasarkan uraian di atas, maka perlu dilakukan penelitian tentang penggunaan sumbu sabut kelapa terhadap pertumbuhan tanaman pada sistem hidroponik sebagai solusi bagi petani yang memiliki lahan terbatas.

\section{METODE PENELITIAN}

\section{Bahan dan Alat}

Bahan yang digunakan dalam penelitian ini adalah benih sawi hijau, kain flanel, sabut kelapa, dan nutrisi hidroponik AB-MIX. Sedangkan alat-alat yang digunakan adalah wadah kaca, ember, gayung, gelas ukur, penggaris, timbangan, TDS meter, $\mathrm{pH}$ meter, dan wadah penyemaian.

\section{Parameter Penelitian}

Parameter penelitian yang diamati adalah suhu lingkungan, kelembaban udara, intensitas cahaya, evapotranspirasi tanaman, dan pertumbuhan tanaman.

\section{Prosedur Penelitian}

\section{Suhu Lingkungan}

Pengukuran suhu lingkungan dilakukan untuk melihat perbedaan suhu di dalam dan di luar greenhouse. Pengamatan suhu lingkungan dilakukan pada pagi hari, siang hari, dan sore hari. Pengukuran suhu di dalam greenhouse dilakukan dengan cara meletakkan alat sensor suhu di antara tanaman dan atap greenhouse.

2. Kelembaban Udara

Pengukuran kelembaban udara atau Relative Humidity (RH) dilakukan pada pagi hari, siang hari, dan sore hari. Kelembaban udara di dalam greenhouse diukur dengan meletakkan alat humidity meter di antara tanaman dan atap greenhouse. Sedangkan kelembaban di ruang penanaman diukur dengan meletakkan alat humidity meter di tengah-tengah tanaman (Aulia, dkk., 2019).

3. Evapotranspirasi Tanaman

Pengukuran evapotranspirasi tanaman dilakukan untuk melihat volume kehilangan air pada setiap hari. Evapotranspirasi tanaman diukur dengan cara mengamati perubahan ketinggian air dalam pot menggunakan penggaris. Pengamatan evapotranspirasi tanaman dilakukan pada pagi hari, siang hari, dan sore hari.

4. Intensitas Cahaya

Pengukuran intensitas cahaya dilakukan menggunakan lux meter. Lux meter ditempatkan di antara tanaman dengan perlakuan jarak pengukuran mengikuti pertumbuhan tinggi tanaman. Intensitas cahaya diukur pada pagi hari, siang hari, dan sore hari (Aulia, dkk., 2019).

5. Pertumbuhan Tanaman

Tinggi tanaman diukur dari perbatasan antara akar dan batang sampai daun tertinggi pada masing-masing tanaman. Pengukuran dilakukan menggunakan penggaris. Pengukuran ini dilakukan seminggu sekali.

Prosedur penanaman pada teknologi hidroponik adalah:

1. Wadah diisi larutan nutrisi dengan $\mathrm{pH}$ yang tepat lalu diaduk secara manual sampai larutan tercampur merata.

2. Masing-masing wadah diisi dengan larutan nutrisi yang sudah dibuat.

3. Dilakukan pemindahan tanaman dari persemaian ke media tanam.

4. Dilakukan adaptasi di dalam greenhouse selama 1 minggu.

5. Dilakukan pemindahan tanaman sistem wick dari greenhouse ke rumah tanaman yang telah disediakan.

6. Dihidupkan pompa.

7. Dilakukan pengamatan setiap hari sampai tanaman dapat dipanen selama 4 minggu.

Tahap pembuatan rumah tanaman yang digunakan pada penelitian ini adalah:

1. Dipersiapkan alat dan bahan yang diperlukan.

2. Dibuat rumah tanam dengan ukuran $49 \mathrm{x}$ 35 x $30 \mathrm{~cm}$.

3. Diberi papan sebagai penyangga net pot dengan ukuran $49 \mathrm{~cm}$.

4. Net pot dipasang di tengah-tengah papan. 

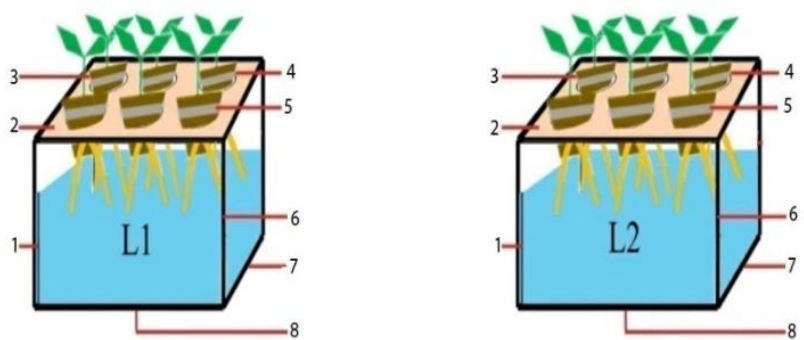

Gambar 1. Skema Ruang Tanam

Tahapan pembuatan larutan nutrisi yang digunakan pada penelitian ini adalah:

1. Disiapkan 2 buah wadah dan diisi dengan air bersih masing-masing 5 liter

2. Ditandai masing-masing wadah yaitu wadah A dan wadah B.

3. Dibuka kemasan nutrisi A dan dimasukkan ke dalam wadah A kemudian diaduk sampai air dan serbuk nutrisi tercampur merata dengan sempurna membentuk sebuah pekatan.

4. Dibuka kemasan nutrisi B dan dimasukkan ke dalam wadah B kemudian diaduk sampai air dan serbuk nutrisi tercampur merata dengan sempurna membentuk sebuah pekatan.

5. Dimasukkan $25 \mathrm{ml}$ larutan pekatan A dan 25 ml larutan pekatan B kedalam 5 liter air kemudian diaduk sampai tercampur merata dengan sempurna. Kemudian larutan siap digunakan.

Tahapan pembuatan sistem sumbu (wick) pada penelitian ini adalah:

1. Dipersiapkan alat dan bahan yang diperlukan.

2. Dibuat lubang pada pada sterofom.

3. Dimasukkan kain flanel ke dalam lubang yang telah dibuat pada tutup botol.

4. Dimasukkan larutan nutrisi ke dalam botol bagian bawah

5. Dimasukkan benih sawi yang telah berumur 14 hari ke dalam botol bagian atas

6. Menempatan sterofom ke dalam wadah kaca.

Pengujian jenis dan panjang sumbu terhadap pertumbuhan dan hasil produksi tanaman adalah:

1. Dihidupkan pompa pada ruang tanam yang telah diisi dengan tanaman sawi.

2. Diatur jarak tanam.

3. Diamati pertumbuhan tanaman sawi dari jenis sumbu dan panjang sumbu.

\section{Analisis Data}

Data hasil penelitian dianalisis menggunakan analisis sidik ragam. Apabila nilai $\mathrm{F}$ hitung lebih besar dari nilai $\mathrm{F}$ tabel berarti terdapat pengaruh yang signifikan dan sebaliknya apabila nilai $\mathrm{F}$ hitung lebih kecil dari nilai $\mathrm{F}$ tabel, berarti tidak terdapat pengaruh yang signifikan. Hasil analisis ini ditampilkan dalam bentuk grafik (Ansar dan Sirajuddin, 2012).

\section{HASIL DAN PEMBAHASAN}

\section{A. Suhu Lingkungan}

Pengamatan suhu lingkungan dilakukan untuk melihat perbedaan suhu di greenhouse dan di dalam ruang tanam yang bertujuan untuk mengetahui faktor yang mempengaruhi keadaan di dalam ruang tanam (Tabel 1).

Tabel 1. Nilai Rata-rata Suhu Lingkungan di Luar Greenhouse

\begin{tabular}{cccc}
\hline \multirow{2}{*}{$\begin{array}{c}\text { Minggu } \\
\text { ke- }\end{array}$} & \multicolumn{3}{c}{ Suhu di Luar Ruang Tanam (Lingkungan) } \\
\cline { 2 - 4 } & Pagi & Siang & Sore \\
\cline { 2 - 4 } & $\begin{array}{c}(07.00-08.00 \\
\text { WITA) }\end{array}$ & $\begin{array}{c}(12.00- \\
13.00\end{array}$ & $\begin{array}{c}(16.00-17.00 \\
\text { WITA) }\end{array}$ \\
& WITA) & \\
\hline 1 & 27,2 & 33,3 & 34,3 \\
2 & 28,6 & 37,1 & 31,7 \\
3 & 29,2 & 38,2 & 36,0 \\
4 & 29,9 & 36,3 & 35,7 \\
$\begin{array}{c}\text { Rata- } \\
\text { rata }\end{array}$ & 28,7 & 36,2 & 34,4 \\
\hline
\end{tabular}

Suhu udara di suatu tempat pada waktu tertentu dapat disebabkan oleh panas matahari yang di terima bumi. Berdasarkan kondisi suhu di luar ruang tanam dapat diketahui bahwa suhu di luar ruang tanam mempengaruhi suhu di dalam ruang tanam, sehingga apabila suhu di luar ruang tanam meningkat, maka suhu di dalam ruang tanam ikut meningkat. Suhu di dalam ruang tanam relatif lebih tinggi dibandingkan suhu di luar ruang tanam. Hal ini terjadi karena di dalam ruang tanam dengan menggunakan penyinaran buatan yang menghasilkan panas, dan suhu di luar ruang tanam masuk dan menambah suhu di dalam ruang tanam. Suhu di dalam ruang tanam berangsur-angsur lebih tinggi 
pada saing hari jika dibandingkan pagi hari dan sore hari.

Berdasarkan hasil penelitian diketahui bahwa suhu di luar ruang tanam pada pagi hari mencapai $28,7^{\circ} \mathrm{C}$, siang hari mencapai $36,2^{\circ} \mathrm{C}$ dan sore hari mencapai $34,4^{\circ} \mathrm{C}$. Sedangkan suhu di dalam greenhouse pada pagi hari mencapai $28,8^{\circ} \mathrm{C}$, siang hari mencapai $36,3{ }^{\circ} \mathrm{C}$, dan sore hari mencapai $34,4^{\circ} \mathrm{C}$. Suhu udara pada siang hari lebih tinggi untuk pertumbuhan tanaman sawi, sehingga daun tanaman cepat mengalami kelayuan, namun hanya bersifat sementara karena pada sore hari tanaman kembali normal. Suhu udara pada pagi hari dan sore hari sangat sesuai untuk tanaman sawi. Menurut Iritani (2012), suhu udara yang diinginkan oleh tanaman sawi untuk pertumbuhan adalah 20-28 ${ }^{\circ} \mathrm{C}$.

\section{B. Kelembaban Udara}

Kelembaban udara (relative humidity, HR) merupakan kadar kandungan uap air di udara (Ansar, dkk., 2010). Kelembaban udara dibutuhkan tanaman untuk menjaga agar tanaman tidak cepat kering dan mati karena proses penguapan yang terjadi dan kelembaban merupakan faktor ligkungan yang penting untuk pertumbuhan tanaman.

Selama penelitian berlangsung nilai ratarata kelembaban udara pada siang hari realtif lebih rendah dibandingkan pada pagi hari dan sore hari, hal ini disebabkan karena pada siang hari suhu udara lebih tinggi dibandingkan pada pagi hari dan sore hari, tetapi pada hari-hari tertentu pada siang hari kelembaban udara lebih tinggi dibandingkan pada pagi hari dan sore hari, hal ini disebabkan karena pada siang hari terjadi mendung dan hujan sehingga suhu udara menjadi menurun dan kelembaban udara menjadi naik. Nilai rata-rata kelembaban udara di luar ruang tanam dan di dalam ruang tananam dapat dilihat pada Tabel 2.
Tabel 2. Nilai Rata-rata Kelembaban Udara di Luar Greenhouse

\begin{tabular}{cccc}
\hline \multirow{2}{*}{$\begin{array}{c}\text { Minggu } \\
\text { Ke- }\end{array}$} & \multicolumn{3}{c}{ Kelembaban Udara di Luar Ruang } \\
\cline { 2 - 4 } & Pagi & Siang & Sore \\
\cline { 2 - 4 } & $(07.00-$ & $(12.00-$ & $(16.00-17.00$ \\
& 08.00 & 13.00 & WITA) \\
& WITA) & WITA $)$ & \\
\hline 1 & 73.5 & 50.1 & 52 \\
2 & 68.7 & 41.1 & 48.1 \\
3 & 70.1 & 40.7 & 42 \\
4 & 66 & 44.2 & 37.7 \\
Rata-rata & 69.5 & 44.0 & 44.9 \\
\hline
\end{tabular}

Berdasarkan hasil pengamatan

kelembaban udara di luar ruang tanam pada pagi hari adalah $69,5 \%$, pada siang hari $40 \%$, dan pada sore hari $44.9 \%$. Sedangkan kelembaban udara di dalan greenhouse pada pagi hari adalah $71 \%$, siang hari $45,6 \%$, dan sore hari $46,8 \%$. Menurut Haryanto, dkk. (2002), kelembaban udara yang sesuai untuk pertumbuhan tanaman sawi berkisar antara 80-90\%. Kelembaban udara yang lebih tinggi dari $90 \%$ berpengaruh buruk terhadap pertumbuhan tanaman yakni tanaman tumbuh tidak sempurna, tanaman tidak subur, kualitas daun jelek. Kelembaban udara juga berpengaruh terhadap proses penyerapan unsur hara tanaman yang diikuti oleh meningkatnya pertumbuhan tanaman.

Selama pengamatan berlangsung, kelembaban udara pada masing-masing ruang tanam sudah sesuai yang dibutuhkan tanaman pada pagi hari dan sore hari. Namun, pada siang hari kelembaban udara kurang sesuai dengan kebutuhan untuk tanaman sawi karena pada siang hari suhu udara meningkat Apabila suhu meningkat, maka kelembaban udara menurun. Hal ini terlihat pada siang hari daun tanaman sawi cepat layu dan kering.

\section{Intensitas Cahaya}

Intensitas cahaya juga merupakan faktor lingkungan yang penting untuk pertumbuhan tanaman. Cahaya bagi tanaman dapat melakukan proses metabolisme yang akan berlangsung dalam batang, daun, dan akar. Intensitas cahaya di dalam greenhouse pada pagi hari sebesar 2,113 lux, siang hari sebesar 26,316 lux, dan sore hari 3,102 lux. Intensitas cahaya dalam greenhouse masih kurang dari intensitas cahaya 
yang dibutuhkan tanaman sawi karena kondisi greenhouse yang ternaungi oleh plastik UV sebagai atap greenhouse, rumah-rumah yang tinggi dan pepohonan di sekitar penempatan greenhouse. Hasil pengukuran intensitas cahaya seperti disajikan pada Tabel 3.

Tabel 3. Intensitas Cahaya (Lux)

\begin{tabular}{cc}
\hline Perlakuan & $\begin{array}{c}\text { Intensitas } \\
\text { cahaya }(\text { Lux })\end{array}$ \\
\hline Sumbu $20 \mathrm{~cm}(\mathrm{~T} 1)$ & 2.217 \\
Sumbu $30 \mathrm{~cm}$ (T2) & 2.565 \\
Sumbu 20 cm (L1) & 1.753 \\
Sumbu 30 cm (L2) & 1.918 \\
\hline
\end{tabular}

Berdasarkan Tabel 3, diketahui bahwa rata-rata intensitas cahaya tertinggi di dalam greenhouse yaitu pada siang hari sebesar 26,316 lux. Hal ini dikarenakan pada siang hari sinar matahari mencapai puncak, sehingga sinar matahari masuk melalui celah pada atap-atap atau ventilasi bangunan. Sore hari nilai rata-rata intensitas cahaya di dalam greenhouse sebesar 3,102 lux. Hal ini diduga terjadi karena pada sore hari sinar matahari yang masuk hanya sedikit. Sedangkan pada pagi hari intensitas cahaya sebesar 2,113 lux lebih kecil dibandingkan dengan sinar matahari yang masuk pada sore hari. Fenomena ini terjadi karena pada pagi hari matahari mulai mengeluarkan cahaya, sedangkan pada sore hari matahari sudah mulai terbenam.

Berdasarkan hasil penelitian intensitas cahaya di dalam ruang tanam tertinggi terdapat pada ruang tanam T2 sebesar 13,243 lux karena posisi ruang tanam yang berada di tengah-tengah greenhouse. Intensitas cahaya pada ruang tanam L2 sebesar 10,512 lux. Hal ini disebabkan oleh posisi ruang tanam yang tidak jauh berbeda dari T2. Intensitas cahaya pada ruang tanam T1 sebesar 10,053 lux dan intensitas cahaya terendah terdapat pada ruang tanam L1 sebesar 8,234 lux. Hal ini disebabkan oleh posisi ruang tanam yang di naungi oleh pepohonan di luar greenhouse dan faktor lainnya adalah posisi ruang tanam yang berada di pojok greenhouse.

\section{Evapotranspirasi Tanaman}

Evapotranspirasi diukur dengan melihat penurunan atau kehilangan air pada tanaman setiap hari. Evepotranspirasi tanaman dapat diperoleh dari hasil pengamatan perubahan ketinggian air dalam ruang tanam menggunakan penggaris. Pengukuran evapotranspirasi menggunakan metode pengurangan yaitu volume awal dikurangi dengan volume akhir dan perhitungan evapotranspirasi menggunakan koefisien tanaman $(\mathrm{Kc})$.

Evapotranspirasi harian yang terjadi pada tanaman sawi setiap perlakuan mengalami kenaikan. Hal ini disebabkan oleh beberapa faktor diantaranya, suhu, kelembaban, intensitas cahaya, dan kondisi tanaman. Faktor lingkungan juga berpengaruh terhadap besarnya penguapan. Dari data yang diperoleh, pada ruang tanam bersirkulasi memliliki nilai evapotranspirasi tertinggi dibandingkan dengan perlakuan non sirkulasi. Hal ini disebabkan pada perlakuan sirkulasi tanaman lebih tinggi, daunnya lebih lebar, dan akarnya lebat di bandingkan dengan perlakuan non sirkulasi (Gambar 2).

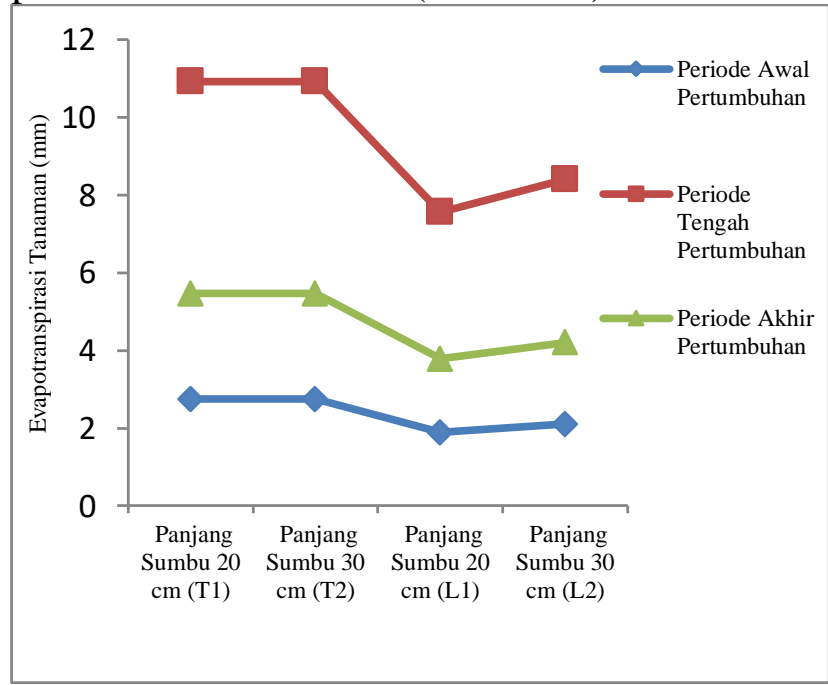

Gambar 2. Evapotranspirasi Tanaman pada Masing-masing Ruang Tanam

Evapotranspirasi tanaman sawi meningkat pada minggu ke-3 pada setiap perlakuan. Hal ini terjadi karena pada minggu ke-3 pertumbuhan vegetatif tanaman sawi mencapai titik maksimal, sehingga luas permukaan daun tanaman lebih lebar. Kondisi tanaman seperti luas daun juga berpengaruh terhadap penguapan, sehingga proses evapotranspirasi semakin meningkat. 
Prihmantoro dan Indriani (1999) telah menjelaskan bahwa penguapan air berpengaruh terhadap kebutuhan air tanaman. Semakin tinggi penguapan, maka semakin banyak air yang dibutuhkan. Tanaman sawi pada dasarnya membutuhkan air yang banyak. Kandungan air dalam tanaman hanya sebagian kecil dari air yang dihisap tanaman, yang kemudian digunakan untuk metabolisme tanaman.

\section{E. Pertumbuhan Tanaman}

Pertumbuhan tanaman dapat dilihat berdasarkan banyaknya daun yang sudah terbuka sempurna. Pengamatan daun dilakukan selama pemanenan tanaman sawi. Hasil pengamatan jumlah daun dapat dilihat pada Tabel 4. Jumlah daun merupakan faktor penting pada proses pertumbuhan tanman sawi karena tanaman sawi merupakan tanaman sayuran yang bagian batang dan daunnya dapat dimanfaatkan. Semakin banyak jumlah daun, maka pertumbuhan tanaman sawi semakin baik. Berdasarkan Tabel 4, jumlah daun pada masing-masing perlakuan T1 sumbu flanel sebanyak 3 helai, T1 sumbu sabut kelapa sebanyak 7 helai, T2 sumbu flanel sebanyak 4 helai dan T2 sumbu sabut kelapa sebanyak 8 helai. Kemudian L1 sumbu flanel sebanyak 2 helai, L1 sumbu sabut kelapa sebanyak 3 helai, dan L2 sumbu flanel sebanyak 2 helai, dan L2 sumbu sabut kelapa 5 helai.

Tabel 4. Pertumbuhan Tanaman Sirkulasi (T) Dan Non Sirkulasi (L)

\begin{tabular}{|c|c|c|c|}
\hline Perlakuan & $\begin{array}{c}\text { Tinggi } \\
\text { Tanaman } \\
(\mathrm{cm})\end{array}$ & $\begin{array}{c}\text { Jumlah } \\
\text { Daun } \\
\text { (Helai) }\end{array}$ & $\begin{array}{c}\text { Indeks } \\
\text { Luas } \\
\text { daun } \\
(\mathrm{cm})\end{array}$ \\
\hline $\begin{array}{l}\text { T1 Sumbu flanel (20 } \\
\mathrm{cm})\end{array}$ & 3.96 & 3 & 10.5 \\
\hline $\begin{array}{l}\text { T1 Sumbu sabut kelapa } \\
(20 \mathrm{~cm})\end{array}$ & 6.5 & 7 & 18.6 \\
\hline $\begin{array}{l}\text { T2 Sumbu flanel (30 } \\
\mathrm{cm})\end{array}$ & 4.66 & 4 & 15.9 \\
\hline $\begin{array}{l}\text { T2 Sumbu sabut kelapa } \\
(30 \mathrm{~cm})\end{array}$ & 10.33 & 8 & 20.6 \\
\hline $\begin{array}{l}\text { L1 Sumbu flanel (20 } \\
\mathrm{cm})\end{array}$ & 3 & 2 & 4.6 \\
\hline $\begin{array}{l}\text { L1 Sumbu sabut kelapa } \\
(20 \mathrm{~cm})\end{array}$ & 3.83 & 3 & 7.2 \\
\hline $\begin{array}{l}\text { L2 Sumbu flanel (30 } \\
\mathrm{cm})\end{array}$ & 3.5 & 2 & 6.7 \\
\hline $\begin{array}{l}\text { L2 Sumbu Sabut kelapa } \\
(30 \mathrm{~cm})\end{array}$ & 5.8 & 5 & 11.15 \\
\hline
\end{tabular}

Berdasarkan hasil pengamatan daun terbanyak pada perlakuan T2 sumbu sabut kelapa, sedangkan jumlah daun paling sedikit pada perlakuan L1 sumbu flanel. Hal ini disebabkan oleh tanaman sawi pada L1 banyak mengalami kelayuan yang ditandai dengan bercak kering pada daun, sehingga menyebabkan daun menjadi berkurang setiap minggu. Selain itu pertumbuhan tanaman sawi belum optimal karena intensitas cahaya kurang dan menggunakan sistem hidroponik pasif artinya air nutrisinya menggenang tidak bersirkulasi, sehingga tanaman kekurangan oksigen. Pertamawati (2010), telah melaporkan bahwa proses fotosintesis dapat optimal apabila daun yang menjadi tempat utama proses fotosintesis semakin banyak jumlahnya dan semakin besar ukurannya.

\section{KESIMPULAN DAN SARAN}

\section{Kesimpulan}

Berdasarkan hasil dan pembahasan dapat disimpulkan bahwa:

1. Jenis sumbu berpengaruh terhadap laju pertumbuhan dan perkembangan tanaman sawi. Sumbu sabut kelapa memiliki jumlah daun lebih banyak dibandingkan dengan sumbu flanel.

2. Produktivitas tanaman yang dihasilkan dari jenis sumbu sabut kelapa lebih baik jika dibandingkan dengan sumbu kain flanel.

3. Panjang sumbu tidak berpengaruh terhadap produktivitas tanaman yang dihasilkan.

4. Hasil pertumbuhan tanaman dengan sistem sirkulasi air lebih baik jika dibandingkan dengan sistem non sirkulasi air. Hal ini dapat dibuktikan dari hasil rata-rata jumlah daun dan tinggi tanaman.

\section{Saran}

Penelitian ini hanya menggunakan media yang terbuat dari kaca dan memberikan hasil yang belum optimal, sehingga perlu dilakukan penelitian lebih lanjut dengan media tanam lain agar tanaman dapat tumbuh secara optimal. 


\section{DAFTAR PUSTAKA}

Adiyoga, (1999). Analisis Sistem Irigasi Hidroponik NFT (Nutrient Film Technique) pada Budidaya Tanaman Selada (Lactuca sativa var. crispa. L). Skripsi. Departemen Teknologi Pertanian. Fakultas Pertanian. Universitas Sumatera Utara.

Ansar dan H.A. Sirajuddin, (2012). Model Matematis Kenaikan Suhu Pada Butiran Selama Pengepresan Pada Pembuatan Tablet Effervescen Buah Markisa. Jurnal Agritech UGM, 32(4): 418-425.

Ansar, B. Rahardjo, N. Zuheid, dan Rochmadi, (2010). Pengaruh Suhu dan Kelembaban Udara terhadap Perubahan Mutu Tablet Effervescen Sari Buah selama Penyimpanan. Jurnal Teknologi dan Industri Pangan IPB, 22(1): 73-77.

Aulia, S., Ansar, dan GMD. Putra, (2019). Pengaruh Intensitas Cahaya Lampu dan Lama Penyinaran terhadap Pertumbuhan Tanaman Kangkung (Ipomea Reptans Poir) pada Sistem Hidroponik Indoor. Jurnal Ilmiah Rekayasa Pertanian dan Biosistem, 7(1): 44-52.

Cahyono, B., (2003). Teknik dan Strategi Budidaya Sawi Hijau (Pat-Tsai). Yogyakarta: Yayasan Pustaka Nusatama.

Iritani, G., (2012). Vegetable Garding Menanam Sayuran di Perkarangan Rumah Jenis Buah Mangalap. Yogyakarta: Indonesia Tera.

Haryanto, E., T. Suhartini, dan E. Rahayu, (2002). Sawi dan Selada. Jakarta: Penebar Swadaya.
Lee, C.W., I.S. So., S.W. Jeong., and M. R. Huh, (2010). Aplication of Subirrigation Using Capillary Wick System to Pot Production. Journal of Agriculture \& Life Science, 44 (3): 7-14.

Lingga, P., (2005). Hidroponik Bercocok Tanam Tanpa Tanah. Jakarta: Penebar Swadaya.

Mas'ud Poerwowidodo. 1993. Telaah Kesuburan Tanah. Angkasa.Bandung.

Pertamawati, (2010). Pengaruh Fotosintesis terhadap Pertumbuhan Tanaman Kentang (Solanum Tuberosum L.) dalam Lingkungan Fotoautrif secara Invitro. Jurnal Sains dan Teknologi Indonesia, 12(1): 31-37.

Prihmantoro, H dan Y.H. Indriani, (1999). Hidroponik Sayuran Semusim untuk Bisnis dan Hobi. Jakarta: Penebar Swadaya.

Rosliani, R. dan N. Sumarni, (2005). Budidaya Tanaman Sayur dengan Sistem Hidroponik. Balai Penelitian Tanaman Sayur Pusat Penelitian dan Pengembangan Hortikultura Badan Penelitian dan Pengembangan Pertanian. Bandung.

Sopandie, D., (2006). Persfektif Fisiologi dalam Pengembangan Tanaman Pangan di Lahan Marjinal. Orasi Ilmiah Guru Besar Tetap Fisiologi Tanaman. Fakultas Pertanian, IPB. Bogor.

Wesonga, J.M., C. Wainaina, F.K. Ombwara, P.W. Masinde, and P.G. Home, (2014). Wick Material and Media For Capillary Wick Based Irrigation System in Kenya. International Journal of Science and Research, 3(4): 613-617. 